\title{
Ethnicity and Belonging as Experienced Dimensions in Mixed Marriages
}

\author{
Ursula Apitzsch \\ Eran Gündüz \\ Johann Wolfgang Goethe Universität \\ apitzsch@soz.uni-frankfurt.de \\ merans@gmx.de
}

Received: 17-11-2010

Accepted: 17-11-2011

\begin{abstract}
The first part of this article offers a theoretical outline of the concepts of ethnicity and belonging. It also explains the history of ethnicity. The theory chapter deals with three fields of interest: gender and belonging, belonging as biographical positioning and the question of multiple belonging. The second part of the article includes different views expressed in the media and public debate on problems related to migration in European countries. It especially calls into question the debate in Germany given its reductionist perspective on the national, religious and cultural identity of its migrants. The authors highlight the inherent bicultural identity in the second generation of immigrant families. This is illustrated in the case of a young Kurdish Turk who not only grew up in Germany but is married to a woman with a German family background. This is therefore an example of a "mixed couple“. Thus, the authors conclude that there is no way to identify a person unambiguously with one particular ethnic belonging. According to them, the factor that unifies the diverse affiliations of a person, a couple and their offspring is the biographical work of each individual, not an all-embracing ethnicity.
\end{abstract}

Key words: ethnic groups; cultural belonging; Germany; mixed couples.

\section{Resumen. Etnicidad y pertinencia como dimensiones vividas en las parejas mixtas}

La primera parte del artículo presenta los conceptos de etnicidad y pertinencia. Además, explica la historia de la etnicidad. El capítulo teórico trata tres campos de interés: «género y pertinencia», "pertinencia como posicionamiento biográfico» y la cuestión de "pertenencia múltiple». La segunda parte del artículo incluye diferentes puntos de vista expresados a través de los medios de comunicación y el debate público sobre problemas relacionados con la migración en los países europeos. Se cuestiona, especialmente, el debate en Alemania debido a su perspectiva reduccionista de la identidad nacional, religiosa y cultural de sus migrantes. Los autores destacan la identidad bicultural inherente a la segunda generación de las familias de inmigrantes. Todo ello se muestra en el caso de la biografía de un joven 
turco kurdo. Éste no sólo se crió en Alemania sino que además está casado con una mujer con un trasfondo familiar alemán. Así pues, este caso sería un ejemplo de "pareja mixta». Por todo ello, los autores concluyen que no es posible identificar claramente a una persona mediante su pertenencia étnica. Consecuentemente, el factor que une las diferentes afiliaciones de una persona, una pareja y sus hijos es más bien el esfuerzo que cada uno realiza en el marco de su biografía y no su pertinencia a una etnicidad externa.

Palabras clave: grupos étnicos; pertenencia cultural; Alemania; parejas mixtas.

\section{Summary}

I. The Concepts of Ethnicity and

Belonging. A Theoretical Outline

(Ursula Apitzsch)
II. Double Cultural Orientations in a Mixed Couple and the Question of Identity (Eran Gündüz)

Bibliographic References

\section{The Concepts of Ethnicity and Belonging. A Theoretical Outline (Ursula Apitzsch)}

\section{I.1. On the history of the concept of ethnicity}

Although "ethnicity" is derived from the Greek word ethnos, today it by no means signifies a people's consciousness that they form a collective. In his Politics, Aristotle distinguished between the ethnos, the native citizens of Athens, and the demos, the rest of the population. In the contemporary world, the meanings of these terms in everyday usage have been reversed: "ethnics" are always the others, and the autochthonous population does not think of itself as an ethnic group. As Lepsius (1988) emphasizes, "ethnos" has come to mean a traditional community, while modern, post-traditional society sees itself as a "demos", people acting collectively by democratic rules.

Max Weber was both the first scholar to grasp the modern, social-constructivist sense in which we speak of "ethnic groups" and the most sophisticated analyst of this question. In Economy and Society, originally published in 1922 but written before the First World War, Weber defined the characteristic selfconsciousness of ethnic groups as their "group affinity, regardless of whether it has any objective foundation". He speaks here of the "artificial origin of the belief in common ethnicity" and defines it as follows "We shall call "ethnic groups' those human groups that entertain a subjective belief in their common descent because of similarities of physical type or of customs or both, or because of memories of colonization and migration; this belief must be important for the propagation of group formation; conversely, it does not matter whether or not an objective blood relationship exists." 1 Weber argues that if

1. Max Weber, Economy and Society, eds. Guenther Roth and Claus Wittich, Berkeley: University of California Press 1978, p.389. 
ethnicity is asserted to be an original quality, God-given or provided by nature, it can be a useful way of pursuing interests in struggles over scarce resources.

Weber sees a fluid transition from ethnic to racist group definitions here: ${ }^{2}$ "The sense of ethnic honor is a specific honor of the masses (Massenehre), for it is accessible to anybody who belongs to the subjectively believed community of descent. The 'poor white trash' i.e. the propertyless and, in the absence of job opportunities, very often destitute white inhabitants of the southern states of the United States of America in the period of slavery, were the actual bearers of racial antipathy, which was quite foreign to the planters. This was so because the social honor of the 'poor whites' was dependent upon the social déclassement of the Negroes". ${ }^{3}$

Understood in this way, ethnicity is a complex social concept which sees that the ascription of certain qualities to oneself or others is a matter of construction, but at the same time suggests that the groups which do this instrumentalize these ascriptions by claiming that they are natural groups.

In the tradition of Robert Park and the Chicago School, however, ethnic groups are not only seen as marginalized but also as culturally and politically productive groups. When Weber travelled through the USA in 1904, he was able to observe for the first time the political formation of the black population and the work of the black civil rights activists Booker T. Washington and William E.B. Du Bois, and became interested in this form of legitimate ethnic positioning. These encounters led Weber to the conviction that the explicit prohibition of marriage between blacks and whites in the southern states of the USA was a direct consequence of the emancipation of the slaves and struggles for civil rights. The notorious "one drop rule" stated that a single drop of black blood in a white person's ancestry, whatever their origins, meant they were automatically discriminated against and excluded from participation in civil affairs. In this way, white groups monopolized social power and honor by the racial construction of themselves and the others. ${ }^{4}$

2. There is an endless discussion in sociology about the appropriateness and the relation of the terms "race" and "ethnicity" to each other. Smelser, Wilson and Mitchell (2001) say: "Because race and ethnicity contain such a complex array of sustaining mechanisms and overlapping connotations, consistent definitions are hard to come by. Even the great sociology master, Max Weber, was frustrated in his efforts to deal with them." (ibid. p.3) In my view, Weber takes ethnicity as the broader concept, because it means not only ascription (which in the case of the déclassement of black people by the 'poor white trash' Weber would call "racial"), but also self-positioning. My own use of "ethnicity" is still broader than Weber's, because (according to the concept of Stuart Hall) I also include meanings of ethnicity as different (imposed) positionings and their reflection by biographical work. For the history of discussion on the concepts of "race" and "ethnicity" see Bös 2005.

3. Weber, ibid.391.

4. "Apart from the laws against biracial marriages in the Southern states, sexual relations between the two races are now abhorred by both sides, but this development began only with the Emancipation and resulted from the Negroes' demand for equal civil rights. Hence this abhorrence on the part of the Whites is socially determined by the ... tendency toward the monopolization of social power and honor, a tendency which in this case happens to be linked to race." (Weber; ibid., p.386). 
Today new pan-ethnic categories such as "African-American", "AsianAmerican" etc. in the US are also being interpreted as a result of the failure of social integration and the discrimination that follows from this. These panethnic categories are seen as motivated by "the political requirements of competition for equal rights and material resources" (Neckel, 1995: 217-228, A7). "The demand that is now being put forward is no longer social integration regardless of all ethnic differences, but rather an officially guaranteed share of rights and resources that depends on the size and situation of the ethnic group." (Neckel, 1995: 230)

We can see at this point that ethnicity can be conceived of in very different ways if it is connected to the concept of societal participation. On the one hand, when we think about Weber's example of the "ethnic honor" of the "poor white trash" in the southern states of the US after the Civil War, it coincides exactly with what Talcott Parsons later called "ascription" and contrasted with "achievement". In the case of the devaluation of the other by ascription of certain "natural" qualities it means involuntary membership as distinct from the possibility of subjective positioning in society. Astonishingly, though, the very societal groups that have been the objects of ethnicizing identifications like the black civil movements in the US consciously appropriated the term in a positive way, in order to pay tribute to the historical achievement of their group.

\section{I.2. Gender and Belonging}

In the modern nation state, the concept of ethnicity has a strong relationship with the category of gender. In traditional societies, the ethnic honor of men was usually connected with the patriarchal definition of proper behavior of women, particularly in relation to biological reproduction. In modern contract-based societies, the position of members of society is no longer defined by honor but by rights and duties. Carol Pateman, however, fears that the contract model of "fraternalism", or the nation as fraternity, which is replacing paternalism, does not in principle recognize that women have any public rights and duties. Rather, it banishes them from the public space of brothers and pushes them into the private space where paternalist power has survived (Pateman, 1988: 4). This idea seems plausible to the extent that it is able to explain the constant private violence of men against women. Nira Yuval-Davis assumes that in classical contract theories, women are considered to be, so to speak, closer to nature, whatever this "nature" may be in terms of ethnicity.

In mixed marriages, patriarchal patrilinear law can be overridden by a stronger consideration, the creation of "natural" belonging and ethnic "honor" or "dishonor". In one section of her 1997 book Gender and Nation, YuvalDavis relates an example from Britain: 
"A man from Ghana tried in the 1970s to claim his British origin, stating the partiality clause in the British Immigration Act, and arguing that his African grandmother was legally married to his British grandfather. The judge rejected his claim, arguing that at that period no British man would have genuinely married an African woman" (Yuval-Davis, 1997: 27).

It is noticeable that in this case there is a domination of patriarchal juridical concepts by racist arguments about belonging, and there is a further insinuation to the effect that a certain female person is entirely without honor. The legal position of patrilinear descent is not abandoned altogether, but in an individual case the attributed ethnicity is assigned a higher value as an indicator of belonging than legally grounded participation.

This observation is of some importance for the assessment of the mysterious way in which ethnic belonging functions as a construct. We recognize that ethnic belonging is a construct that can be handled in different ways in individual cases, but this does not make ethnic attribution any less socially dangerous —on the contrary, it makes it more dangerous and unpredictable. The example of the genocide in Rwanda illustrates this. Many Tutsi women who were married to Hutu men fled during the massacres to neighboring states, especially South Africa. There they told of their terrible experiences and fears. Their children should have been protected against persecution by the Hutus because Hutus observe the rule that family belonging is passed down via patrilinearity, but they were not able to trust this form of belonging as protection against genocide. ${ }^{6}$ The reasons given as ways of defining ethnicity can change, and one must constantly check to see if they are connected with ensuring control over the resources of a group. It is important to note that such definitions of belonging can by no means be considered as self-evident and more original and fundamental than the construction of belonging by societal contract or personal choice. Rather, they are themselves constantly in need of re-examination. Groups defined as minorities by the dominant society and described as ethnic groups, or which have described themselves as such, have thus begun to reflect upon the history of ethnic ascriptions and to make themselves part of their particular national history by narrating their own victimization.

\section{I.3. Belonging as biographical positioning and Multiple Belonging}

In view of the obvious dangers implicit in the ascription of individual ethnicity, ${ }^{7}$ it is reasonable to ask anew why scholars like Stuart Hall, for example, have argued that the concept of ethnicity should be consciously appropri-

6. Ingrid Palmary, a psychologist who coordinates the Gender, Violence and Displacement Initiative at the University of Witwatersrand, has reported on the topics that dominate the biographical narratives of the women affected. (Ingrid Palmary: The Construction of Race and Violence Against Women. The example of the Hutu and the Tutsi. German version in: Migrantinnen, Grenzen überschreitend. Das Argument 266, H.3/2006, p.402-410.)

7. See also the examples given by Gabriele Rosenthal (2004) from the former Yugoslavia. 
ated in a positive way in order to pay tribute to the historical positioning and achievement of marginalized groups. The category is appropriate, Hall argues, precisely because the black subject and the black experience are not defined by nature. The concept of ethnicity can be used to construct that subject historically, culturally, and politically, and this can be done by the subject itself (Hall, 1994: 21f.).

This way of looking at the issue is legitimate and productive as long as there are politically positioned groups and individuals who succeed in reversing ethnicizing processes of identification and stratification, giving them their own meaning, and so reinterpreting them biographically. This requires spaces for such groups' own experiences, the appropriation and reshaping of a wide range of traditions, and media and intellectual discourses that are at the disposal of these groups.

The idea of participation on the basis of citizenship rights established by a contract (as we have known it since the Enlightenment in the thought of Locke, Hume, Rousseau, and Kant) had to struggle from the start with the problem of the actual real conditions of an unequal and unjust society. The model does not explain who is permitted to conclude the contract, who is allowed to join, how relations between the autochthonous population and those joining later are to be regulated, and so on. It is true that our contemporary concepts of citizenship draw a fundamental distinction between a ius sanguinis, a "blood right" to participate that is guaranteed by heredity, and a ius soli, derived from the Latin solum meaning soil, i.e. the derivation of rights to citizenship from the territorial principle, as it has been formulated since the French Revolution. Historically, though, there never existed a pure ius soli (Brubaker, 1992). The French revolutionary armies, and after them Napoleon's armies, spent long periods outside French territory, but it goes without saying that they did not want to lose their rights as French citizens and that they also wanted to pass these rights on to their children, who might be born from mixed marriages outside France. Countries under greater pressure from immigration constantly had to deal with the opposite problem - how to define rules for participation that would protect the established citizens. Historically, therefore, the idea of participation on the basis of a territory shared by those inhabiting it has always been combined with various other principles for the definition of belonging. The most important of these is, without doubt, the principle that those who belong are those whose parents already belonged. Kant's imagined idea of the nation as children of the same parents arises from people's desire to be able to pass on their own position and resources in a privileged way to the next generation. The feudal state gave its subjects the feudal right to pass these privileges on, and the bourgeois state redefined them via the institution of property and - if necessary - via the various ways of defining ethnic belonging.

In conclusion, we have to state that in all historical contexts "belonging" is always already an underlying condition of participation. Instead of ignoring it or only unmasking it as invention or pure illusion, we should study it very 
concretely not only as ascription but also as a possible achievement, in the ways it is being re-constructed in everyday practice by biographical work as well as collective positioning. A sociologist would be able to demonstrate that the image of the first "Black President" Barack Obama is a pure construct because Obama has two white and two black grandparents. Why isn't he called white and not black? At the same time, Obama's election as president has acquired its moving historical significance because millions of people identify with him as members of a group with a common history of being regarded and treated as unequal, and of having grandparents who were not allowed to eat in a restaurant. At the same time, we know that Obama belongs to lots of different groups. He is not only black, he also belongs to an elite, to the group of the most influential American intellectuals, and he is also a member of a Christian church and has a Christian identity as distinct from a Muslim one. In a word: he belongs to groups in multiple ways, and is not only defined by black ethnicity.

However, ethnic belongings are mostly not freely chosen. They are imposed on individuals by ethnic politics, and the individuals have to live through different ethnic regimes in order to reorganize their and their families' biographies through biographical work and through coping with different group identifications throughout their lives. This means that they have to exercise different ethnic positions in face of dominating or dominated social powers, but that as individuals they are never defined by just one ethnicity. So we would argue that, instead of speaking about ethnicity without groups (as Rogers Brubaker does), we should speak about ethnic groups without ethnic individuals.

\section{Double Cultural Orientations in a Mixed Couple and the Question of Identity (Eran Gündüz)}

Through the case of a young Turkish-Kurdish man married to a German woman $^{8}$, who will be given the name Efe, we want to raise the question of the impact that his original "biculturality" could have had on his choice of partner. By doing this we will also be able to shed some light on the question of the formation of a new cultural identity of the couple and the possible transformative character of mixed couples for migration societies.

The case of Efe is taken from the French-German comparative study "Conjugalités mixtes: mode de formations conjugales et dynamiques familiales des descendants d'immigrés en France et en Allemagne". ${ }^{9}$ This research project and its field work were carried out in 2005 and 2006 under the direc-

8. Taken from the German-French research project: "Conjugalités mixtes: mode de formations conjugales et dynamiques familiales des descendants d'immigrés en France et en Allemagne” under the direction of Beate Collet and Lena Inowlocki.

9. In France the research project was conducted by Beate Collet and Emmanuelle Santelli, and was financed by the Human Sciences Institute in Lyon and the INED in Paris. The German research team at the Goethe University, Frankfurt was headed by Lena Inowlocki and composed of Eran Gündüz, Irini Siouti, Julia Jancsó and Jutta Niang. The German part of the study was financed by the Balzan Foundation (Italy/Switzerland). 
tion of Beate Collet and Lena Inowlocki. ${ }^{10}$ In total 80 biographical interviews were conducted with 20 couples in Germany and 20 couples in France. In Germany the couples under investigation had to fulfil the criterion that one partner was a member of the second Turkish "guest worker" generation. In France, the interviewed couples had to fulfil the criterion that one member of the couple was from the second Maghrebian generation in France. Thus, the research focused on the "marriage behaviour" of members of the second generation of Maghrebian and Turkish immigrants in both countries, in order to reach findings on their marriage patterns. According to the methodology of Grounded theory, the approach to the field of study was guided by theoretical assumptions.

The research was interested in identifying differences in both countries, and focused on questions of lived citizenship (citoyenneté vécue) and cultural belonging among the group under investigation. ${ }^{11}$

The research group found three different constellations of couple formation cases: (1) The second generation member was married with a partner from the country of origin, having immigrated only for marriage; (2) cases which we can call "mixed couples" where the second generation member formed a couple with someone of another ethnic/cultural background; and (3) cases of couples formed of two persons belonging to the second generation. The third constellation was the least frequent case.

We have chosen the case of Efe out of this briefly described sample, which as noted above contains different constellations, in order to exemplify certain aspects of the empirical field - for example the question of cultural belonging of a second generation member, and also his relation to the "majority culture" through his marriage to a "genuine" German woman. Thus, the case discussed in this article does not serve to generate all the theoretical theses on ethnicity and belonging as presented in the first part of this article, but is linked to them by illustrating the aspects of cultural belonging in a specific case of a "mixed marriage". The aim is to illustrate that cultural belonging and positioning is highly complex, particularly in the discussed case of a second-generation member of Turkish-Kurdish origin, who grew up in Germany and is married to a member of the majority group.

In other words, the case of Efe shows that multiple belonging is not only possible but also a lived reality for the second generation of immigrants.

\section{II.1. A critique of a simplistic view of identities}

As mentioned above, at latest since the events following 9/11 we might observe in the European immigration countries, so as in Germany, the

10. See Collet Beate, Santelli Emmanuelle (2006), Les conjugalités mixtes des descendants d'immigrés en France et en Allemagne: Modes de formation conjugale et dynamiques familiales, Rapport de recherche remis à l'Institut des sciences de l'Homme, Lyon, octobre 2006.

11. See the antecedent works of Beate Collet (1996 and 1998). 
shift in the media, political and even in scientific discourse ${ }^{12}$ which stands for a reductive and simplistic view of the cultural identity of the so-called "Muslim migrants." We want illustrate this simplification briefly through the example of the immigrants and their descendants coming from Turkey. Although nearly a fifth of the Turkish immigration group is Alevi $(600,000-$ $700,000)$, the approach to this group is to view them as a homogenous group of Turkish-Muslims. However, the immigrants of Turkish origin in Western countries are extremely heterogeneous and belong to different ethno-cultural groups, such as Kurds, Armenians, Arabs and others. Concerning the religious aspect there is a similar diversity: There are for example Christians, Yezidi, or Jews. ${ }^{13}$ We have to add to this heterogeneity of the immigration population stemming from Turkey the fact that Turkey is officially a secular state which distinguishes between the religious and public sphere. This means also that a significant quantity of the Turkish population and Turkish immigrants share secular values. For this group the religious identity is not primary, they do not even practice Islam.

Why does this aspect matter when we talk about mixed couples? Because it gives us the elements to question a simplistic view of identities, and in our case even the expression of bicultural marriages, who itself can contribute to a reductive view of the cultural identity of persons comprising a "mixed couple". Of course, the same heterogeneity can be said of the majority societies and that is why we need to have a differentiated view on mixed couples.

\section{II.2. The question of cultural identity in mixed couples}

Following Gabriele Rosenthal (1999) identity and belonging to a group will be reconstructed as a biographical process under permanent change. According to this understanding of identity, different elements of the identity of a person can become dominant in different life stages. Rosenthal sees identity not as belonging to a collective, but rather as belonging to a specific personal biographical experience the background of which is a family history. This family history is for its part embedded in different collectives and the social world.

In modern western societies based in general on the principle of the homogenous national culture - except some cases such as Spain, Switzerland or Belgium, where different cultural groups form the nation- immigration might challenge the self-definition of the classical nation-states. Can we maintain this also for the case of the (probably) increasing number of bicultural couples? Will they and their children have the potential to challenge a monocultural understanding of belonging to the nation-state?

12. See for example Necla Kelek (2005), Die fremde Braut: ein Bericht aus dem Inneren des türkischen Lebens in Deutschland, Köln: Kiepenheuer \& Witsch

13. Zentrum für Türkeistudien (1998): Das ethnische und religiöse Mosaik der Türkei und seine Reflexionen auf Deutschland, Zentrum für Türkeistudien Essen (ed.), Münster: LIT 
The case of Efe might show the social and cultural distance between migrants stemming from Turkey and the fear of these migrants of being assimilated by the majority culture and finally of being "dissolved". For the long term the mentioned hybridisation of culture could lead - interpreted in a more positive way - to a veritable political community where the origin of the members doesn't play a crucial role in belonging to this community.

\section{II.3. The case of Efe}

Here, we want to present the case of Efe, since it illustrates on the one hand the biographical process in becoming a German and the quasi rational choice to live "as Germans do" (Efe). On the other hand the interview with Efe is an impressive example of the 80 interviews conducted in the project "Conjugalités mixtes" ("mixed marriages") which shows the social and cultural distance between his Turkish-Kurdish family and the majority society. This is obvious in the fact that Efe had great difficulties to tell his parents that he has a German girl friend. The marriage which took place in the middle of 2005 has apparently contributed to a change of the self-perception of Efe's relatives within their extended family. In the interview Efe mentions that not only he but also his family are seen and treated differently by their relatives since the marriage.

Efe was 27 years old when the author conducted the interview with him in 2005. Together with his family he left Turkey for Germany in 1990. At that period he was 11 years old. After their immigration to Germany the family tried to obtain asylum. Efe has a little sister married to a relative since 2003. In 1997 he got a diploma from the middle school ("Hauptschule", which represents the lowest level of the three levels existing in the differentiated German school system). Due to the difficulties to get a permanent residential permit he couldn't find an employer ready to offer him a position where he could continue his professional education. In the following years he had to earn money by working as a taxi driver and a cashier in a gas station. At the time of the interview he continued working at the gas station, but with the encouragement of Anne, his wife, he began training in retail sales. Efe met Anne in the frame of his football club where Anne came often to watch the matches of her former boy friend.

As I said above, the relationship between Anne and Efe was difficult at the beginning, because Efe had to hide his relationship. After several separations, Efe decided in 2004 to talk openly with his parents about his desire to live with Anne. Anne was 31 years old at the time of the interview and she had a son of 5 years from her former relationship. She is a teacher at the primary school.

Despite the difficulties to make his parents accept his relationship with a German woman Efe says in the interview that he feels quite happy to live with Anne because he identifies stronger with the German culture than with the Turkish. 
"And I believe I'd rather that she was a German and not a Turk 'cause I didn't want all those Turkish things, and be a part of it, yeah. That doesn't mean that I give the Turkish culture up, or that I find it bad, yeah. For God's sake. That's just because, I would say, I didn't see any progress in myself until the age of 24. (...) And then I just said that the German or European way of life is what I would prefer for my future. And if I could do that with a Turkish woman - I don't know it, I had my doubts about that, yeah. You can try it with a Turkish woman, but mostly it doesn't work." (Transcript Efe, 158-169)

Efe grew up in a family milieu where the relations with the relatives and the ethnic group had an important place in the social life. But when he was still a child he preferred staying at home and playing football or basketball with his German friends while the rest of the family went to visit their relatives. According to Efe's own words he decided to live in a German way but he did not give up the Turkish culture. However, Efe did not express during the whole interview any identification with a group in the sense of "I'm German" or "I'm Turkish". The at least two groups in question seem rather to serve as reference frames or cultural systems with which he is able to act in his daily life. They give him orientation.

He sees the restrictions in his family and relatives milieu, which he calls "my Turkish people" as a reason for the stagnation in his life. Probably, his behaviour and his retrospective view on his life can be interpreted as the desire to be emancipated from the life style of his parents and his relatives.

"That's the milieu, of course. There hasn't been any progress. When I was in this circle of my let's say Turkish people. It has never been so, I never had the feeling that I can learn something from these people. I don't want to say that they are bad people. For God's sake. Everybody should care of his own life, but - so how their daily life is, or their lives (...) I don't want to live to be sixty that way." (Transcript Efe, 190-197)

Many of his relatives didn't consider it very good that he wanted marry a German woman, also the mother of a 5-year-old boy from her former relationship.

Efe talks about the wedding with nearly 1000 guests where some of them acted as if they where at a funeral.

"All the relatives were there. But, when you looked at them, it was like a cemetery for them or something like that." (Transcript Efe, 518-520)

Efe explains the hostile attitude of his parents with the social pressure coming from the circle of his relatives.

"Nobody says, yeah?, their son married a German woman, how can it be? A single son, and so on and so on, yeah. And that they feel their honour is offended and that they are offended. That their pride gets dirty or broken. That has been always their great fear". (Transcript Efe, 491-495) 
These statements of Efe might show what it means to transgress norms by a bicultural relationship. By choosing a partner outside of his own group he offends their norms and even feels excluded by them. As Efe says, his parents have been liberal in most questions concerning his life, but not for the question of the choice of his partner. Because, as he says, the family honour depends on it. One can wonder also about the frequent use of the notion of "honour" by Efe since "honour" seemed until now to be stronger linked to women.

Since the marriage Efe's relationship with his relatives and friends has changed.

"I respect them, I still accept them nevertheless. I'm still the same person, who respects and accepts everybody just like he is. But I haven't been respected, accepted, as I am now. Just because I wanted to marry a German woman I have been more or less rejected. The distance to the relatives has grown enormously". (Transcript Efe, 530-535)

For Efe's parents the relationships with their relatives seem to have changed because of their German daughter-in-law. And they might have a new, different position within the large network of their relatives circle.

One link should be - after the explanations of Anne, with whom I also conducted an interview - the aspect of the presents offered to the couple during a traditional Turkish-Kurdish wedding. Anne says that presents in form of money — understood as the expression of solidarity with the young couplewere lower than normally to be expected. Anne believes that the fact that she is a German let the relatives believe that the couple would not stay together for a very long time. The lower sums could have been - as Anne supposes- a means to express the disapproval of that union.

\section{II.4. Some final remarks (Ursula Apitzsch and Eran Gündüz)}

The case of Efe illustrates very well the contingency of identities. And in his case - as a son of a migrant family from Turkey- we have to deal with at a double (or maybe in some aspects even a multiple) cultural orientation which has grown biographically. We would like to underline again that the reference to a certain cultural group can differ according to the personal biographical experiences at different stages of life. That means also that elements of personal cultural identity can get a different relevance in a different societal context. Rosenthal studied the cases of Jewish displaced persons after World War Two and found that, related to their place in life, the predominant identity reference could change. She also raises the important question of the biographical function of the reference to cultures or collectives in particular life-stages.

The biographical function of the reference to the German or European life-style in the case of Efe might have an emancipatory character. Thus, a possible interpretation could be that the negative experiences he had made with his own ethnic group could have contributed to his alienation from them and his stronger identification with the German life-style. 
Exactly because what he calls "German culture" is something less concrete it gives him more freedom in the arrangement of his life. The Turkish or Kurdish life-style which corresponds with his very concrete experiences within his family and his ethnic group - as a maybe not well-considered minority group- is seen as restricting, which did not give him the opportunity to evolve personally.

In changing constellations, people recognize themselves as belonging to different collective identities, for example through the mimetic rediscovery of shared resources and codes, but this does not make them into members of a collective subject. Bernhard Peters is surely right when he says that collective identities are a particular sort of social phenomenon, but they are not attributes of individuals (Peters, 2003: 15).

The best proof of this is to be found in analyses of multiple ethno-cultural belongings. In Germany, there are a large number of children of immigrants in the second or third generation who not only speak two standard languages perfectly but also speak one or more dialects to the same standard, i.e. as native languages. Without doubt, they belong to a cultural structure formed in a specific regional context, and can participate in this structure just as they participate in one or more national cultures. As social scientists and biography researchers, we have all experienced the intellectual pleasure to be derived from observing and admiring these forms of linguistic habitus and skilful switching between codes, but there is no way that in doing this we can identify a person unambiguously with one particular ethnic belonging. The factor that unifies these diverse affiliations is the biographical work of each individual, not an all-embracing ethnicity.

\section{Bibliographic References}

Alund, Aleksandra (1997). "Book, Bread and Monument. Continuity and Change Through Ethnic Memory and Beyond», Innovation, Vol. 10(2), pp. 145-160.

ApITZSCH, Ursula (Ed.) (1999). Migration und Traditionsbildung. Opladen: Westdeutscher Verlag.

ApitzsCH, Ursula (1999). «Politik mit der Ethnizität». In: GLATZER, W. (ed.). Ansichten der Gesellschaft. Frankfurter Beiträge aus Soziologie und Politikwissenschaft. Opladen: Leske und Budrich, 374-386.

ApITZSCH, Ursula (2003). «Religious Traditionality in Multicultural Europe». In: SaCkMAnn, R.; Peters, B. and Faist, T. (eds.). Identity and Integration. Migrants in Western Europe. Aldershot: Ashgate, pp. 91-107.

ANDERSON, Benedict (1991), Imagined Communities: Reflections on the Origin and Spread of Nationalism (rev. ed. ). London: Verso.

FREDRIK, Barth (1969). Ethnic groups and boundaries. The social organization of culture difference. Oslo: Universitetsforlaget.

Bös, Matthias (2005). Rasse und Ethnizität. Zur Problemgeschichte zweier Begriffe in der amerikanischen Soziologie. Wiesbaden: VS Verlag.

Bourdieu, Pierre (1991). «Physischer, sozialer und angeeigneter Raum». In: WETZ, M. (ed.). Stadt-Räume. Frankfurt a.M.: Campus, 25-34. 
BRUBAKER, Rogers (2004). Ethnicity without groups. Cambridge: Harvard University Press.

BrubaKer, Rogers (1992). Citizenship and Nationhood in France and Germany. Cambridge: Harvard University Press.

Collet, Beate (1996). Citoyennetés et mariage mixte en France et en Allemagne. École des Hautes Études en Sciences Sociales. Paris: Dissertation. [Mikrofiche-Edit.].

Collet, Beate (1998). "Intégration et Mixogamie en France et en Allemagne». In: Philippe, Claudine; Varro, Gabrielle \& Neyrand, Gérard (eds.). Liberté, Egalité, mixité... conjugales. Une sociologie du couple mixte. Paris: Anthropos, 139-171.

COLLET, Beate and SANTELLI Emmanuelle (2006). Les conjugalités mixtes des descendants d'immigrés en France et en Allemagne: Modes de formation conjugale et dynamiques familiales. Rapport de recherche remis à l'Institut des sciences de l'Homme. Lyon, octobre 2006.

KELEK, Necla (2005). Die fremde Braut: ein Bericht aus dem Inneren des türkischen Lebens in Deutschland. Köln: Kiepenheuer \& Witsch

MECHERIL, Paul (2003). Prekäre Verhältnisse. Über natio-ethno-kulturelle (Mehrfach-) Zugehörigkeit. Münster et al.: Waxmann.

Palmary, Ingrid (2005). "Family resistances. Women, War and the Family in the African Great Lakes». Annual Review of Critical Psychology, 4, 54-65.

PALMARY, Ingrid (2006). «In der Konstruktion von ,Rasse’ steckt Gewalt gegen Frauen». In: Migrantinnen, Grenzen überschreitend. Das Argument, 266, H.3/2006, 402-410.

ParSOnS, Talcott (1951). The Social System. New York: Free Press.

PETERS, Bernhard (2003). "Collective Identity, Cultural Difference and the Developmental Trajectories of Immigrant Groups». In: SACKMANN, R.; PETERS, B. and FAIST, T. (eds.), Identity and Integration. Migrants in Western Europe. Aldershot: Ashgate, 13-36.

RosenTHAL, Gabriele (1999). «Migrationen und Leben in multikulturellen Milieus: Nationale Zugehörigkeit zur Herstellung von familien- und lebensgeschichtlicher Kontinuität». In: ApITZSCH, Ursula (ed.). Migration und Traditionsbildung. Opladen: Westdeutscher Verlag, 22-34

RosenthaL, Gabriele (2004). " "Ethnisierung der Biographie" und Traumatisierung». In: OTTERSBACH, M. und YildiZ, E. (eds.). Migration in der metropolitanen Gesellschaft. Zwischen Ethnisierung und globaler Neuorientierung. Münster: LIT, 217-230.

Smelser, Neil J.; Wilson, William J. \& Mitchell, Faith (eds.) (2001). America Becoming: Racial Trends and Their Consequences, Vol I. Washington D.C.: National Research Council.

Weber, Max (1978). Economy and Society. ed. by Guenther Roth and Claus Wittich, Berkeley: University of California Press.

YuVAL-DaVIS, Nira (1997). Gender and Nation. London: Sage.

ZENTRUM FÜR TÜRKEISTUDIEN ESSEN (ed.) (1998). Das ethnische und religiöse Mosaik der Türkei und seine Reflexionen auf Deutschland. Münster: LIT. 